\title{
Melting Temperature Behavior of Different Energy Crop Ashes
}

\author{
Skaidrīte Būmane ${ }^{1}$, Liena Poiša² ${ }^{2}$ Aleksandrs Adamovičs² ${ }^{2}$ Rasma Platače ${ }^{3}$, \\ Edgars Čubars ${ }^{4}$ \\ Latvian Plant Protection Research Centre, Latvia ${ }^{1}$, Latvian University of Agriculture Latvia ${ }^{2}$, Latvian University \\ of Agriculture Latvia ${ }^{3}$, Rezekne Academy of technologies, Latvia ${ }^{4}$
}

\begin{abstract}
For solid fuels ash melting temperature is recommended to be higher than $1000^{\circ} \mathrm{C}$, so that it can be used in automated furnaces; therefore-promising energy crops are investigated as renewable energy source. This paper presents the results of tests on melting temperature of different energy crop ashes.The field trial was carried out in the study farm of the Latvia University of Agriculture "Pēterlauki" $\left(56^{\circ} 53^{\prime} \mathrm{N}, 2^{\circ} 71 ' E\right)$ in the sod calcareous soils characterized by $\mathrm{pH} \mathrm{KCl} \mathrm{6.7,} \mathrm{P} 52 \mathrm{mg} \mathrm{kg}^{-1}, \mathrm{~K} 128 \mathrm{mg} \mathrm{kg}^{-1}$, organic matter content from 21 to $25 \mathrm{~g} \mathrm{~kg}^{-1}$ in the soil. Energy crops analysed: reed canary grass (Phalaris arundinacea L.), birch (Betula pendula Roth.), osier (Salix spp.), grey alder (Alnus incana (L.) Moench), poplar (Populus tremula L.), hybrid aspen (Populus tremuloides $x$ Populus tremula). Results indicate that the ash melting temperature $(\mathrm{D}, \mathrm{St}, \mathrm{Ht}$, Ft) for the wood energy crops were higher than for the studied grass energy crops and their mixture. Ash melting temperature in all phases over $1200^{\circ} \mathrm{C}$ was observed for such poplar and hybrid aspen mixture proportions: 3 parts of wood and 1 part of reed canary grass, or 1 part of wood and 1 part of reed canary grass.
\end{abstract}

Keywords: ash melting temperature, reed canary grass, birch, osier, grey alder, poplar, hybrid aspen.

\section{INTRODUCTION}

Biomass ashes have a relatively low ash melting temperature - deformation temperature (Dt) is usually in the range of 750 to $1000^{\circ} \mathrm{C}$, compared with coal, which Dt exceeds $1000^{\circ} \mathrm{C}$, as ash chemical and mineralogical composition is very different [1]. Ash melting point of straw is $850-1100^{\circ} \mathrm{C}$ but of coal $1150-1500{ }^{\circ} \mathrm{C}[2]$.

It is important to consider what kind of pellets will be used to heat the heating boiler. For wood pellets the ash percentage is $0.5-1.5 \%$, for straw pellets it is 5 to $10 \%$. Straw pellets have got a very low ash melting point; therefore, a slag layer is formed in the combustion chamber, which, hardens while cooling down and takes up space. If the melting point is below $1000^{\circ} \mathrm{C}$, then particles begin to sinter and the distribution of particles becomes unpredictable.

Ash melting point, defining all four of its standardized values, varies in a very wide range, even within one biomass group; however, on average the deformation temperature is about $1200^{\circ} \mathrm{C}$, which allows to use this fuel for the household and industrial boilers [3]. An important indicator for solid biofuel is the ash melting point for security, burning technology and sediment formation.

Aim of the research: to find out the ash melting point of different energy crops and mixtures thereof in support of energy crop breeding efficiency.

\section{MATERIALS AND METHODS}

Reed canary grass (Phalaris arundinacea L.) was used in the study as grass energy crop. Reed canary grass (RCG) experimental installation conditions: sowing- the third decade of April, place- the study farm of the Latvia University of Agriculture "Pēterlauki" $\left(56^{\circ} 53^{\prime} \mathrm{N}, 23^{\circ} 71^{\prime} \mathrm{E}\right)$, soil- in the sod calcareous soils characterized by $\mathrm{pH} \mathrm{KCl} \mathrm{6.7,} \mathrm{P} 52$ $\mathrm{mg} \mathrm{kg}-1$, $\mathrm{K} 128 \mathrm{mg} \mathrm{kg}^{-1}$, organic matter content from 21 to $25 \mathrm{~g} \mathrm{~kg}^{-1}$ in the soil, additional fertilizerammonium nitrate, harvest time- October, flowering phase- mid-June.

From each fertilizer variable three samples, were taken from an area of reed canary grass $\left(16 \mathrm{~m}^{2}\right)$; which were weighed $\pm 0.01 \mathrm{~kg}$. The samples were used to determine the amount of dry matter. The harvested dry matter was established, by drying the samples in a temperature of $105^{\circ} \mathrm{C}$ until a constant mass remained (ISO 6496). The results were then calculated for a hectare $\left(\mathrm{t} \mathrm{ha}^{-1}\right)$.

The following wood biomass was used for pellet mixture formation: birch (Betula pendula Roth.) form naturally recovered birch sapling hylocomiosa forest type in Baldone district of Zemgale forestry, osier (Salix spp.) - variety 'Thor' from Marupe plantation, gray alder (Alnus incana (L.) Moench), aspen (Populus tremula L.) and hybrid aspen (Populus tremuloides $x$ Populus tremula), which were provided in the form of dry wood powder by Latvian State Forest Research Institute "Silava". http://dx.doi.org/10.17770/etr2017vol1.2642 
Laboratory analysis - the ash melting point was determined according to the standards: LVS CEN/TS 15370-1, EN ISO 17225-1. The study compares five types of pellets, whose composition was as follows: $100 \%$ wood $(\mathrm{w}), 100 \%$ reed canary grass (RCG) $25 \%$ w / 75\% RCG 50\% w / 50\% RCG 75\% w / $25 \%$ RCG.

The results were statistically processed using descriptive and variable statistics, correlation analysis with Microsoft Excel for windows 2000 and the SPSS [4].

\section{RESULTS AND DISCUSSION}

The ash melting point, which determines energy crop quality, is an important indicator that characterizes ash. It has four phases: DT - initial temperature of deformation, ST - melting point, HT Hemispherical temperature, FT - the flow temperature when the melted ash flows over the surface [3]. One of the most important phases is DT because it usually has one of the lowest ash melting phase temperatures.

Also, this study shows that reed canary grass, birch, osier, grey alder, poplar, hybrid aspen DT is over $1200^{\circ} \mathrm{C}$ (Fig. 1). In contrast, the reed canary grass mixtures, whose DT is over $1200^{\circ} \mathrm{C}$, consist of poplar and hybrid aspen. The recommended proportions are as follows: 3 parts of wood and 1 part of reed canary grass, or 1 part of wood and 1 part of reed canary grass.

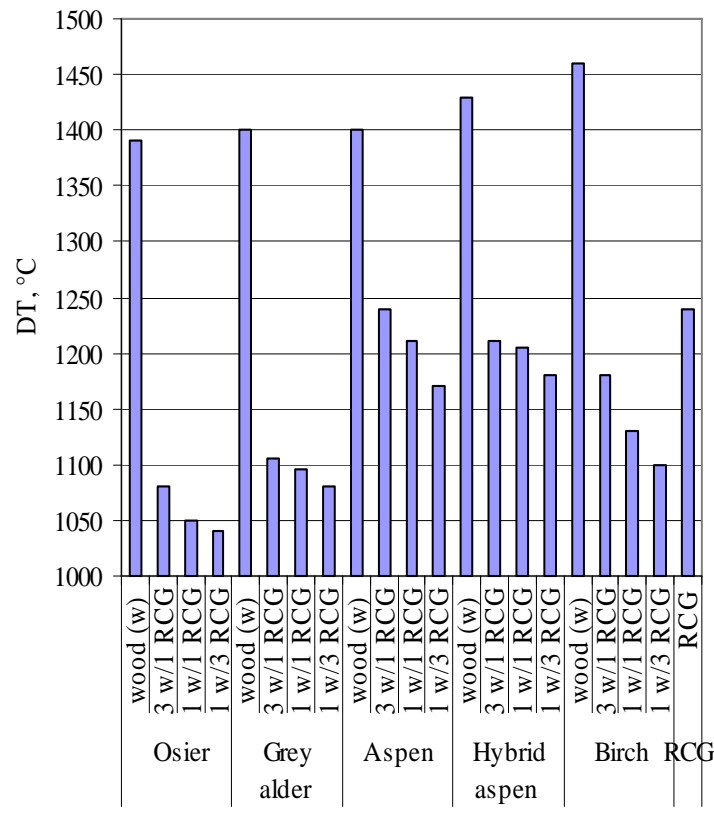

Fig. 1. Deformation temperature (DT) of various energy crops and their mixtures: w- the particular species of wood, RCG - reed canary grass

Initial melting temperature of ash ST over 1200 ${ }^{\circ} \mathrm{C}$ is observed for reed canary grass, birch, osier, grey older, hybrid aspen un RCG mixtures with poplar and hybrid aspen (Fig 2). An osier and hybrid aspen monoculture plantation is a new way to produce woody biofuel in Latvia. When compared RCG mixtures with osier and hybrid aspen biomass, then hybrid aspen biomass is better for mixtures. Observing ash Hemispherical temperature HT and the flow temperature FT over $1200^{\circ} \mathrm{C}$, it is evident that reed canary grass, birch, osier, grey alder, poplar, hybrid aspen and some of RCG mixtures with poplar and hybrid aspen, birch, gray alder are suitable (Fig. 3, Fig. 4).

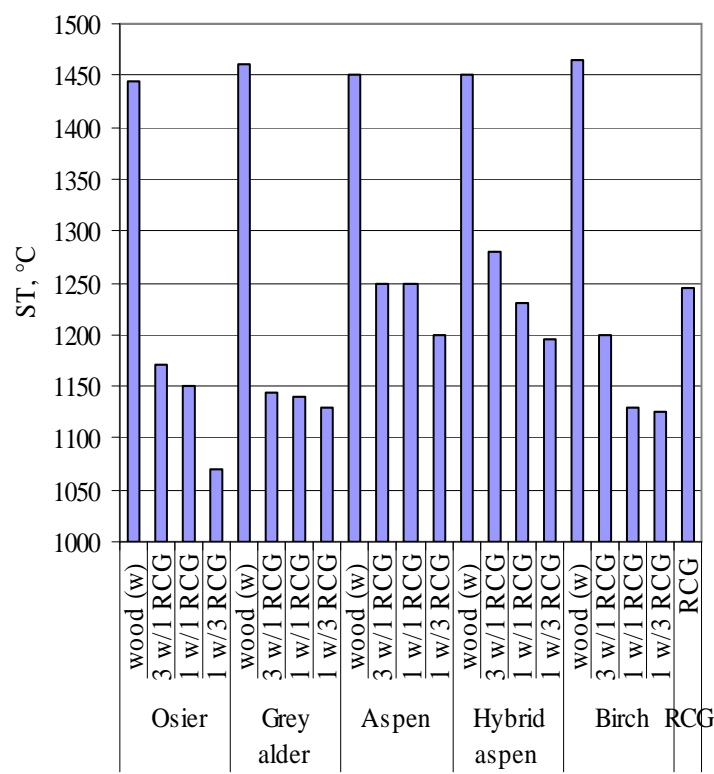

Fig. 2. Initial melting temperature (ST) of different energy crops and their mixtures: w- the particular species of wood, $\mathrm{RCG}$ - reed canary grass

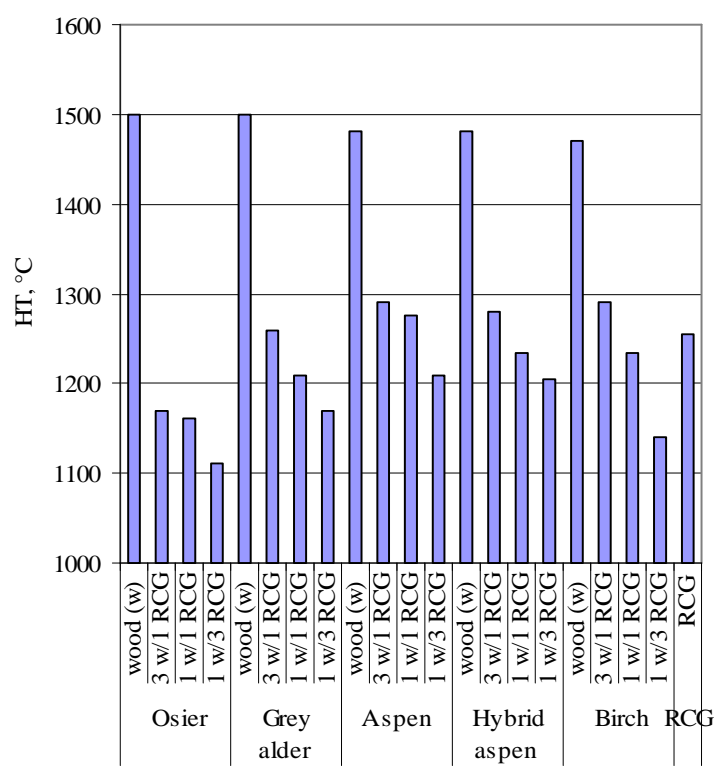

Fig. 3. Hemispherical temperature (HT) for different energy crops and their mixtures: w- the particular species of wood, RCG - reed canary grass 


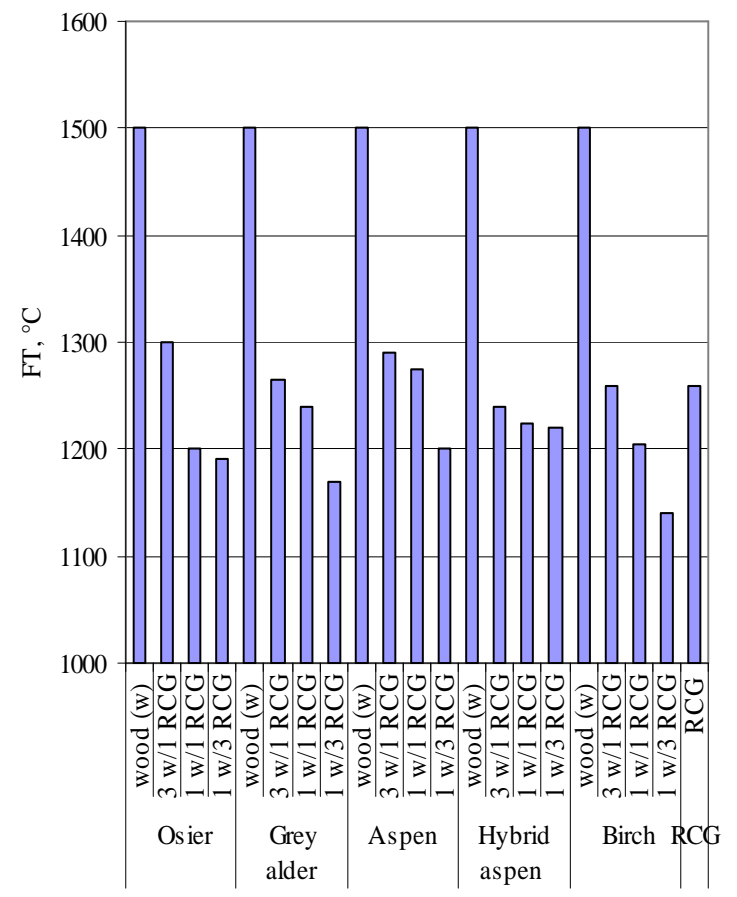

Fig. 4. The flow temperature (FT) for different energy crops and their mixtures: w- the particular species of wood, RCG - reed canary grass

In turn, a lower $\left(<1300{ }^{\circ} \mathrm{C}\right)$ ash melting temperature means that during the combustion of these materials attention should be paid to proper combustion mode to avoid mechanism damage. Accordingly, the alkali metal, phosphorus, chlorine, silica and calcium presence is a determining factors for the ash melting temperature [5], [6]. Reduction of melting temperature is most commonly associated with potassium oxide content increase [3]. Differences in ash melting temperatures within samples of the same plant species, researchers explain by the chemical composition of plants or individual elements, which under the influence of high temperature result in certain chemical reactions [7].

To find out potential relationships of chemical composition of reed canary grass biomass and ash melting temperatures element analysis of biomass was performed. For the reed canary grass dry matter the ash melting deformation temperature forms a negative linear correlation with alkaline and alkaline earth metals $\mathrm{K}, \mathrm{Na}, \mathrm{Ca}(\mathrm{r}=-0.59, P<0.001, \mathrm{r}=$ $0.42 ; P<0.05, \mathrm{r}=-0.55, P<0.001, \mathrm{n}=36)$ but a positive linear connection is formed with $\mathrm{S}(\mathrm{r}=0.57$, $\mathrm{n}=36, P<0.001)$ with phytotoxic elements $\mathrm{As}, \mathrm{Cd}$, $\mathrm{Pb}(\mathrm{r}=0.73, \mathrm{r}=0.63, \mathrm{r}=0.55, \mathrm{n}=36, P<0.001)$. Similar correlations have been also noted for $\mathrm{St}, \mathrm{Ht}$ and Ft.

The research on the reed canary grass yield showed a substantial negative correlation with the ash melting temperature; an positive correlation with carbon, calcium, potassium and sodium in the dry matter, and with the highest calorific yield; a negative correlation with ash content, sulphur content in the dry matter.

For the sustainable production of biofuel it is necessary to use local resources, for example growing of perennial grasses. To facilitate the introduction and to promote environmental protection and energy conservation programmes it will be necessary to utilize the fallow farmland which is not not used for crops or cattle at present. In 2013 it has been noted that Latvia has 342084.29 ha of utilized farmland (LIZ) (312 604.00 ha in 2011) suitable for growing of energy crops [8].

\section{CONCLUSIONS}

Ash melting temperature over $1200^{\circ} \mathrm{C}$ was observed for reed canary grass, birch, osier, grey alder, poplar, and hybrid aspen.

The ash melting temperature in all phases over $1200^{\circ} \mathrm{C}$ was observed for the following poplar and hybrid aspen mixture proportions: 3 parts of wood and 1 part of reed canary grass, as well as for 1 part of wood and 1 part of reed canary grass.

Further research is needed to find the optimal energy crop mixture proportion, where the ash melting temperature would be over $1200^{\circ} \mathrm{C}$.

\section{REFERENCES}

[1] L. Baxter and, J. Koppejan Biomass-coal co-combustion: opportunity for affordable renewable energy. Fuel, vol. 84, 2005, pp. 1295 - 1302.

[2] E. Kronbergs Biomasas konversija enerğijas un mēslojuma ieguvei. Scientific and practical conference: Mehanizācijas un energetikas problēmas lauksaimniecība. April 11-12, 1996, Jelgava, Latvia, pp. 31 - 34

[3] J. Kalnačs, V. Grehovs, D. Grigale, A. Murašovs, and A. Orupe. Koksnes un augu pelnu sastāvs un īpašības, videi labvēlīgas utilizācijas iespējas (Wood and plants ashes content and properties, environment freandly utilisation possibilities). International conference: Eco-Balt. May 15- 16, 2008, Rīga, Latvia, pp. 69.

[4] I. Arhipova and S. Bāliṇa. Statistika ekonomikā (Statistics in economy). Datorzinību centrs, Rīga, 2003. 352 p.

[5] A. Maciejewska A., Veringa H., Sanders J., Peteves S. D. (2006) Co-firing of biomass with coal: constraints and role of biomass pre-treatment. Luxemburg: Office for Official Publications of the European Communities. 100 p.

[6] N. Magasiner, M. van Alphen, M. Inkson, and B. Misplon. Characterising Fuels for Biomass - Coal Fired Cogeneration. International sugar journal, vol. 104, 2002, no. 1242, pp. 251 -267 .

[7] A. Kaḳīis, M. Šmits and I. Belicka. Suitability of crop varieties for energy production. Proceedings of the $8^{\text {th }}$ International Scientific Conference "Engineering for Rural Development", May 28 - 29 2009, Jelgava, Latvia, pp. 188 193.

[8] Lauku atbalsta dienests, [Online]. Available: http://www.lad.gov.lv/lv/par-mums/aktualitates-unpazinojumi/dec-2013/zinami-liz-apsekosanas-rezultati/ [Accessed: Aug. 8, 2014] 